\title{
Shaping fundamental principles of EU law in the area of freedom, security and justice-the ne bis in idem challenge for the $\mathrm{CJEU}$
}

\author{
Corina Badea
}

Published online: 25 August 2012

(C) ERA 2012

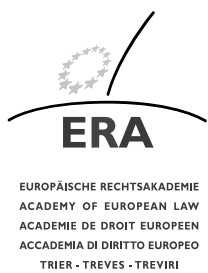

The binding force granted to the EU Charter of Fundamental Rights by the Lisbon Treaty ${ }^{1}$ generated new questions about the interplay between the various legal instruments containing fundamental rights safeguards which impact on judicial cooperation in criminal matters in the EU.

The relationship between Article 4 of Protocol No. 7 of the Council of Europe's Convention on the Protection of Human Rights and Fundamental Freedoms, Article 50 of the Charter of Fundamental Rights of the European Union and Article 54 of the Convention on the Implementation of the Schengen Agreement was the subject of intense debate in a conference organised by ERA in cooperation with the French Court of Cassation in Paris on 3-4 May 2012.

The conference discussions focused both on the transnational aspects of ne bis in idem in the EU-as a fundamental individual right and guarantee for legal certaintyas well as on its national application with regard to the accumulation of administrative and criminal penalties. The latter issue is arising increasingly in connection with sanctions for economic and financial offences due to the autonomous interpretation of the notion "criminal charge" within the meaning of Article 6 of the ECHR. A reflection on the conference discussions and an in-depth analysis are offered by Wolfgang Schomburg and Bas van Bockel in their respective contributions to the this issue of ERA Forum.

\footnotetext{
${ }^{1}$ Treaty of Lisbon amending the Treaty on European Union and the Treaty establishing the European Community, signed at Lisbon, 13 December 2007, entered into force on 1 December 2009.
}

Course Director, C. Badea $(\bowtie)$

Criminal Law Section, Academy of European Law, Metzer Allee 4, 54295 Trier, Germany

e-mail: cbadea@era.int 
The starting point of the conference programme were recent jurisprudential developments, in particular the considerations put forward by Advocate General Kokott in the Toshiba case (C-17/10). Advocate General Kokott ${ }^{2}$ made a powerful plea against the fragmented interpretation of one and the same fundamental principle of EU law. Recalling the different criteria applied in disciplinary proceedings, in state aid proceedings and in criminal law matters, she concluded that

to interpret and apply the ne bis in idem principle so differently depending on the area of law concerned is detrimental to the unity of the EU legal order. The crucial importance of the ne bis in idem principle as a founding principle of EU law which enjoys the status of a fundamental right means that its content must not be substantially different depending on which area of law is concerned. For the purposes of determining the scope of the guarantee provided by the ne bis in idem principle, as now codified in Article 50 of the Charter of Fundamental Rights, the same criteria should apply in all areas of EU law.

The Court however confined its interpretation to competition law matters, thus maintaining the separate lines of interpretation in accordance with the area of law.

The consequences of the Toshiba decision, the state of play of ECtHR and CJEU case law and the current challenges to the coherent realisation of the ne bis in idem principle in the EU are addressed by the contribution of Bas van Bockel.

Since the Toshiba case, two further jurisprudential developments have occurred, touching upon the element of "bis"- the accumulation of administrative and criminal sanctions-one concerning EU agricultural levies fraud (C-489/10) and the other tax matters (C-617/10, pending).

On 5 June 2012 the Grand Chamber ruled in the Bonda Case (C-489/10 ${ }^{3}$ ) upholding the Court's previous findings ${ }^{4}$ that sanctions applied in the framework of the common agricultural policy against beneficiaries which commit irregularities are "a specific administrative instrument forming an integral part of the scheme of aid and intended to ensure the sound financial management of public funds of the European Union", 5 and do not have the nature of a criminal penalty. Thus, such administrative sanctions are not a "bis" in the sense of the EU ne bis in idem principle with the effect of barring further criminal sanctions. The Court pointed out that its earlier statement on the administrative nature of such sanctions is not called into question by the ECtHR case law on Article 4(1) of Protocol No. 7 because by applying the "Engel criteria", 6 the same conclusion is reached: the respective penalties do not have a criminal nature.

\footnotetext{
${ }^{2}$ Opinion of Advocate General Kokott delivered on 8 September 2011 in Case C-17/10 Toshiba Corporation and Others (Reference for a preliminary ruling from the Krajský soud v Brně, Czech Republic), paragraph 117.

${ }^{3}$ Judgment of the Court (Grand Chamber) of 5 June 2012 (reference for a preliminary ruling from the Sąd Najwyższy—Poland)—Criminal proceedings against Łukasz Marcin Bonda.

${ }^{4}$ Case C-210/00 Käserei Champignon Hofmeister [2002] ECR I-6453.

${ }^{5}$ Paragraph 30.

${ }^{6}$ Engel and Others v. the Netherlands, 8 June 1976, $\S \S 80$ to 82, Series A no. 22; the three criteria refer to the legal classification of the offence under national law, the nature of the offence, nature and gravity of the penalty.
} 
Finally, an important pending case is C-617/10, Aklagaren v Hans Åkerberg Fransson, in which Advocate General Cruz Villalón ${ }^{7}$ presented his opinion on 12 June 2012. In contrast with the sanctions against beneficiaries committing irregularities affecting the EU's financial interests, which have a purely administrative nature and thus do not bar further criminal sanctions, the Advocate General concludes that "in line with the case law of the European Court of Human Rights, a tax surcharge imposed in order to ensure compliance with Union law must be regarded as being a substantively criminal penalty" (point 90). He also points out that "the evolution of the case law of the European Court of Human Rights shows that, at the moment, Article 4 of Protocol No. 7 to the ECHR precludes measures for the imposition of both administrative and criminal penalties in respect of the same acts, thereby preventing the commencement of a second set of proceedings, whether administrative or criminal, when the first penalty has become final" (point 79). Taking over the ECtHR case law on ne bis in idem would thus have very far-reaching consequences, particularly in such sensitive fields as sanctioning tax offences. Noting that the accumulation of administrative and criminal sanctions is a widespread practice in many member states in respect of a wide range of offences, as well as that many member states have either not ratified or made reservations in respect to Article 4 of Protocol No. 7 to the ECHR, the Advocate General reaches the conclusion that Article 50 of the Charter calls for a "partially autonomous interpretation" based "exclusively on the wording and scope of Article 50" (point 87).

The interpretation of the Charter in light of the ECHR "must be qualified when the fundamental right in question or an aspect of it (as is the case of the applicability of Article 4 of Protocol 7 to the ECHR to the imposition of both administrative and criminal penalties for the same offence) has not been incorporated fully into national law by the member states" (point 84). Of course, this is the case in relation to the ECHR protocols, not to the Convention as such, to which all the member states are bound. In the Advocate General's view, the widespread practice to impose both an administrative and a criminal penalty for the same offence "could even be described as a common constitutional tradition of the Member States" (point 86).

In sum, the ne bis in idem patchwork in EU law seems to have become even more complicated in the post-Lisbon era. On the one hand, there is the differentiated interpretation in competition and criminal law matters, criticised by Advocate Kokott in the Toshiba case, on the other there is the call for a "partially autonomous interpretation" of Article 50 of the Fundamental Rights Charter, departing from the ECtHR case law in view of the fact that ECHR Protocol 7 is not an international agreement by which all the member states are bound. More clear guidelines regarding the content of ne bis in idem as a fundamental principle of EU law as well as on the situations ${ }^{8}$ when the exercise of public authority needs to be examined in light of this content remain a challenge the CJEU is yet to address.

\footnotetext{
${ }^{7}$ Opinion of Advocate General Cruz Villalón delivered on 12 June 2012 in Case C-617/10 Åklagaren v Hans Åkerberg Fransson (Reference for a preliminary ruling from the Haparanda Tingsrätt, Sweden.)

${ }^{8}$ Interpretation of the Article 51 (1) of the Charter- “only when implementing EU law".
} 